\title{
A FRACTURE-MECHANICS ANALYSIS OF A THIRTY-INCH GAS AUTOCLAVE
}

W. F. Thompson

\section{UNION CARBIDE}

\section{OAK RIDGE Y-12 PLANT \\ OAK RIDGE. TENNESSEE}

prepared for the U.S. ENERGY RESEARCH AND DEVELOPMENT ADMINISTRATION under U.S. GOVERNMENT Contract W-7405 eng 26 


\section{DISCLAIMER}

This report was prepared as an account of work sponsored by an agency of the United States Government. Neither the United States Government nor any agency Thereof, nor any of their employees, makes any warranty, express or implied, or assumes any legal liability or responsibility for the accuracy, completeness, or usefulness of any information, apparatus, product, or process disclosed, or represents that its use would not infringe privately owned rights. Reference herein to any specific commercial product, process, or service by trade name, trademark, manufacturer, or otherwise does not necessarily constitute or imply its endorsement, recommendation, or favoring by the United States Government or any agency thereof. The views and opinions of authors expressed herein do not necessarily state or reflect those of the United States Government or any agency thereof. 


\section{DISCLAIMER}

Portions of this document may be illegible in electronic image products. Images are produced from the best available original document. 


\section{Printed in the United States of America. Available from}

National Technical Information Service

U.S. Department of Commerce

5285 Port Royal Road, Springfield, Virginia 22161

Price: Printed Copy \$4.00; Microfiche $\$ 2.25$

This report was prepared as an account of work sponsored by the United States Government. Neither the United States nor the Energy Research and Development Administration, nor any of their employees, nor any of their contractors, subcontractors, or their employees, makes any warranty, express or implied, or assumes any legal liability or responsibility for the accuracy, completeness or usefulness of any information, apparatus, product or process disclosed, or represents that its use would not infringe privately owned rights. 


\title{
A FRACTURE-MECHANICS ANALYSIS OF A THIRTY-INCH GAS AUTOCLAVE
}

\author{
W. F. Thompson
}

Fabrication Systems Development Department

$Y-12$ Development Division

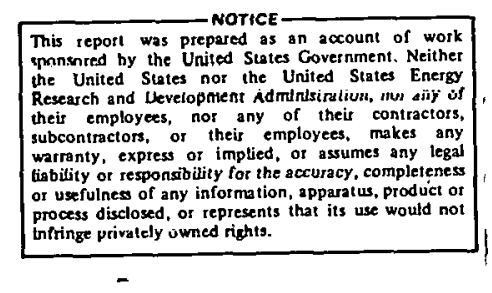

Oak Ridge Y-12 Plant

P. O. Box Y, Oak Ridge, Tennessee 37830

Prepared for the US Energy Research and Development Administration

Under US Government Contract W-7405-eng-26 


\section{ABSTRACT}

Corrosion was found in two areas of a thirty-inch, 103.4-MPa (15,000-psi) gas autoclave. Effects of the corrosion on the fatigue life of the vessel were determined, using a fracture-mechanics approach. 


\section{CONTENTS}

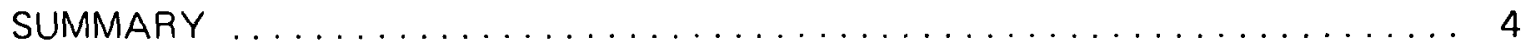

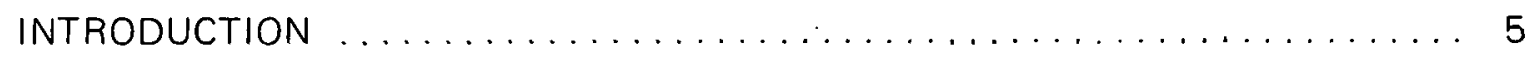

AN ANALYSIS OF PRESSURE VESSEL $2 \ldots \ldots \ldots \ldots \ldots \ldots \ldots \ldots$

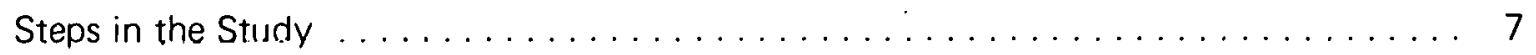

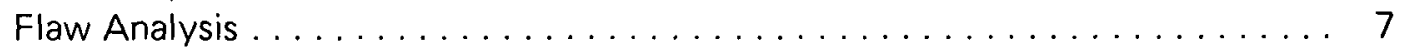

Condition of the Lower Threads $\ldots \ldots \ldots \ldots \ldots \ldots \ldots \ldots \ldots \ldots$

Liner Geometry and Condition ....................... 8

Fracture Analysis of the Lower Thread Region ................ 9

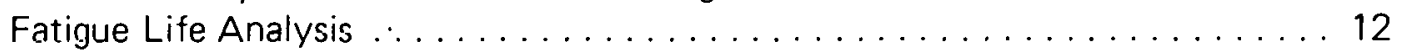

Aluminum Liner Analysis . . . . . . . . . . . . . . . . . . . . . . . . 14

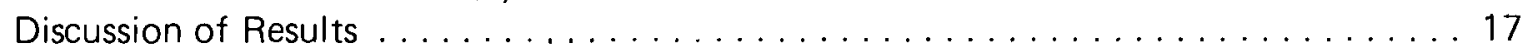

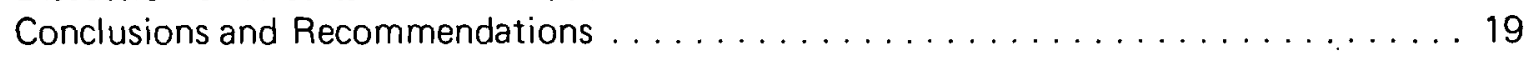

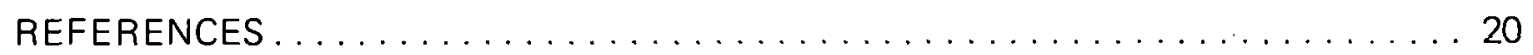




\section{SUMMARY}

After a 30-inch gas autoclave was recently disassembled, corrosion was revealed in an aluminum liner and in the threads of the bottom closure. The corrosion in the bottom threads occurred in the same region where a similar ("twin") pressure vessel had failed, in 1956, due to brittle fracture. The fatigue life of the autoclave was determined, using a fracture-mechanics approach that takes into account the flaws found in the threads and in the aluminum liner.

The major conclusions, as a result of the analysis, are:

1. Corrosion in the aluminum liner and in the bottom thread region appears to be caused by the precipitation of water in the lower region of the autoclave.

2. The fatigue life of the lower thread region should be greater than 97,000 cycles at the maximum operating pressure of $103.4 \mathrm{MPa}$.

3. The life of the aluminum liner is approximately 12,000 cycles, provided excessive corrosion does not occur in the water channels in the liner.

4. The present limit (103.4 MPa) on the maximum operating pressure appears to be a safe and reasonable value. It is recommended that the limit be kept at that level. 


\section{INTRODUCTION}

A thirty-inch gas autoclave at the Oak Ridge Y-12 Plant(a) (PV-2) was recently disassembled, and corrosion was discovered in the lower section of the vessel. The corrosion was confined to two areas: (1) just above the bottom seals in an aluminum liner, and (2) in the roots of the threads at the bottom of the vessel. This corrosion was in the area of failure of a similar vessel (PV-1).

Both pressure vessels (PV-1 and PV-2) were of similar design, as indicated in Figures 1 and 2, in that both were designed as multishell structures with threaded end closures. The pressure chambers measured $0.762 \mathrm{~m}$ ID by 3.048 $m$ deep. PV -1 was designed to operate at a maximum pressure of $207 \mathrm{MPa}$, using mineral oil as the pressing medium. This vessel failed from low-cycle fatigue after 1554 cycles at $207 \mathrm{MPa}$. The failure resulted from catastrophic crack growth around the circumference of the vessel in the root of the first thread of the bottom closure. A detailed study was made on the failure, and several types of tests were made on sections taken from the vessel. A review of the photographs of the failed vessel indicate that an initial crack, $3.28 \mathrm{~mm}$ deep, precipitated the final catastrophic failure.

PV-2 was also designed for a maximum operating pressure of $207 \mathrm{MPa}$, using mineral oil as the pressing medium. However, this vessel has been modified for use as a gas autoclave, and extensive analyses $(1)$ were performed when the vessel was converted. These analyses resulted in the reduction of the operating pressure to $103.4 \mathrm{MPa}$. A water-cooled aluminum liner was also inserted to maintain the vessel walls at room temperature.

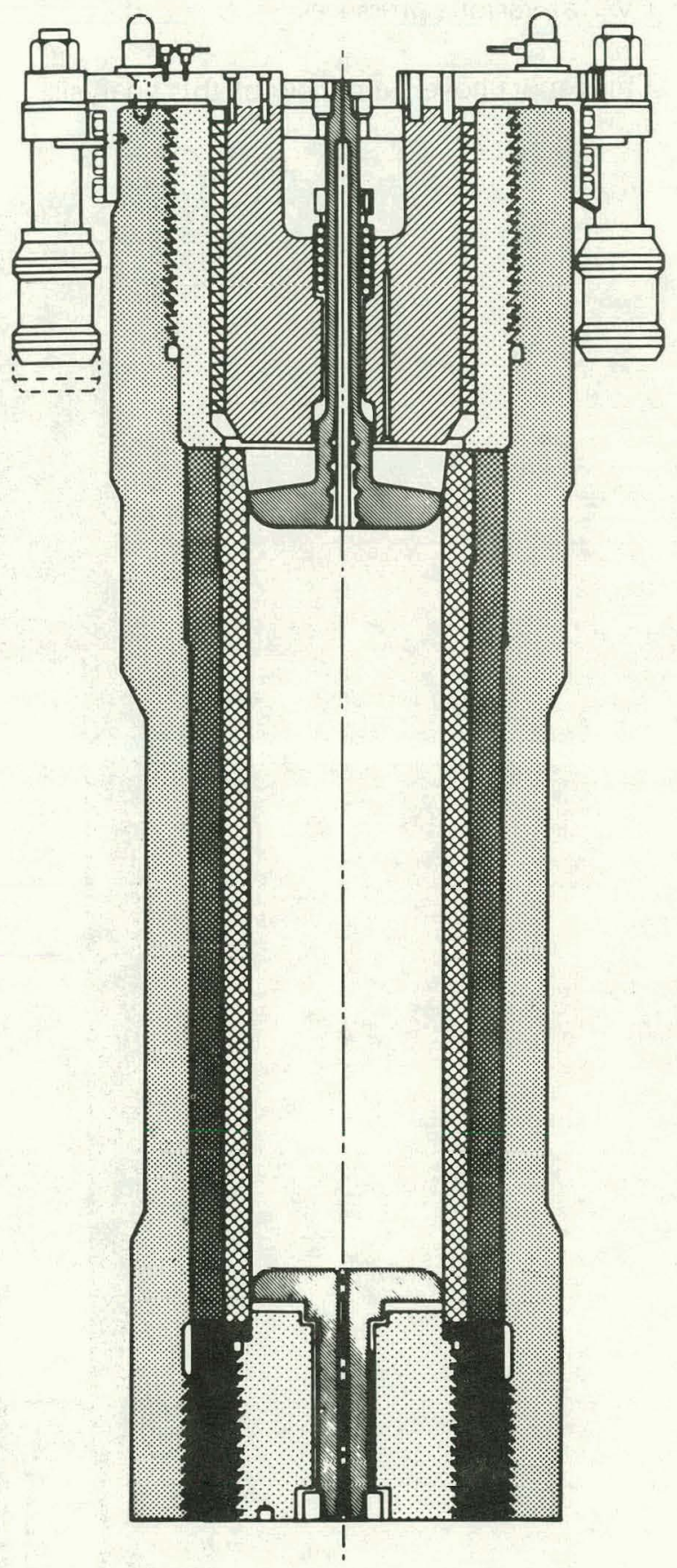

Figure 1. THIRTY-INCH PRESSURE VESSEL. (PV-1)

(a) Operated by the Union Carbide Corporation's Nuclear Division for the US Energy Research and Development Adminstration. 
The purpose of this study was to determine the maximum allowable flaw sizes and the fatigue life of PV-2, using a fracture-mechanics-analysis approach. This study involved three phases: (1) identify the size and cause of the flaws in PV-2; (2) determine suitable analytical models for the analysis of PV-2; (3) predict the critical crack sizes and life for PV-2 at various pressures.

This report covers a review of this analysis.

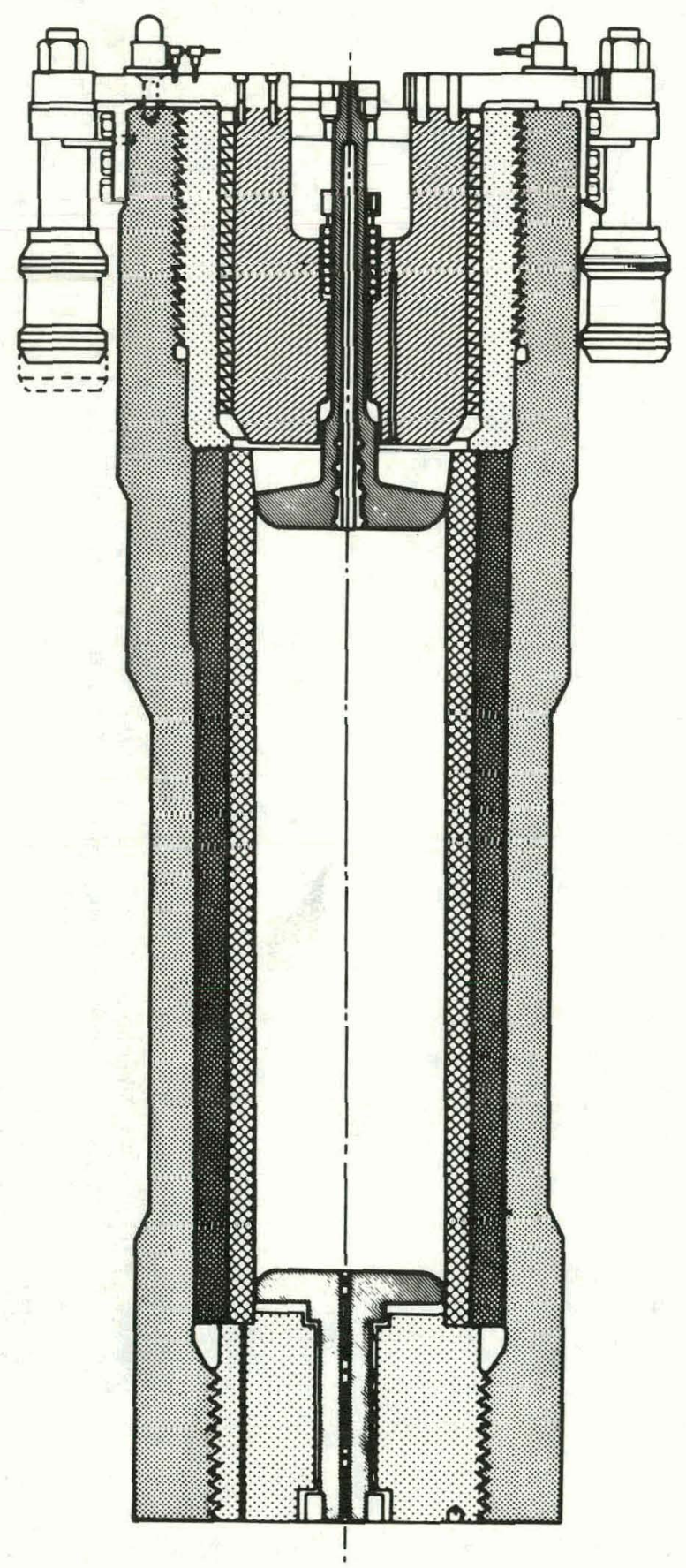

Figure 2. THIRTY-INCH GAS AUTOCLAVE. (PV-2) 


\section{AN ANALYSIS OF PRESSURE VESSEL 2}

\section{STEPS IN THE STUDY}

\section{Flaw Analysis}

Samples were taken of the corrosion products from both the aluminum liner and the threads. The results of the chemical analysis are presented in Table 1. No unusual products were found, indicating that the corrosion was caused solely by the presence of moisture.

\section{Condition of the Lower Threads}

Several areas in the root of the threads had corrosion pits, as seen in Figures 3 and 4 . Hard plastic replicas were made in several areas, and the dimensions of the pits were measured.

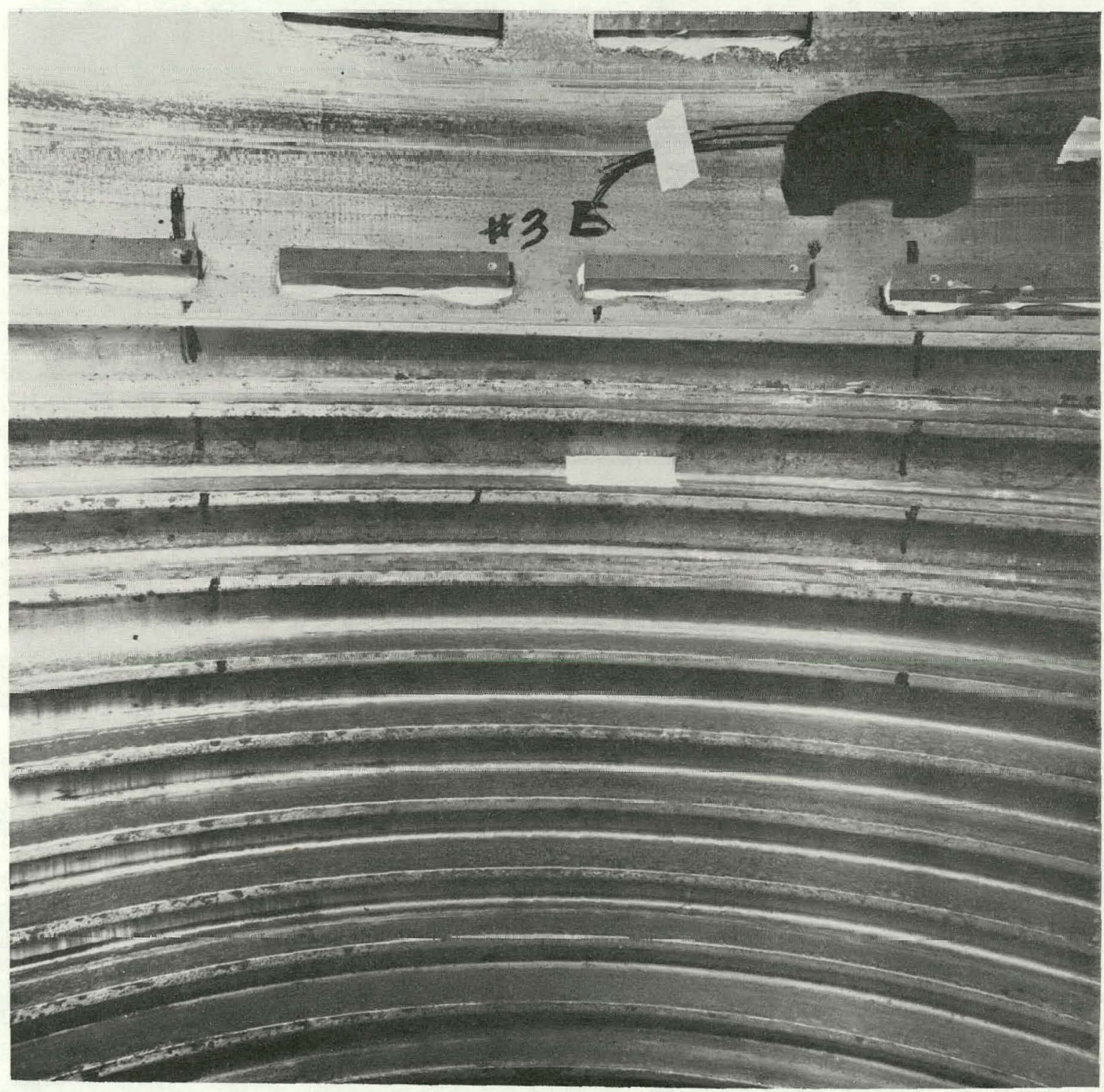

Figure 3. APPEARANCE OF THE BOTTOM THREADS IN PRESSURE VESSEL 2. 
Table 1

CORROSION PRODUCTS OF PV-2

\begin{tabular}{|c|c|c|c|}
\hline Product & & $\begin{array}{l}\text { Corrosion } \\
\text { ample from } \\
\text { ttom Threads }\end{array}$ & $\begin{array}{c}\text { Sample } \\
\text { from } \\
\text { Aluminum } \\
\text { Liners } \\
\end{array}$ \\
\hline Major Constituent & & $\mathrm{Fe}_{3} \mathrm{O}_{4}$ & Al \\
\hline Intermediate Constituent & & Alpha Fe & \\
\hline Minor Constituents & & $\mathrm{FeO}(\mathrm{OH})$ & $\begin{array}{l}\mathrm{Al}_{2} \mathrm{O}_{3} \\
\mathrm{SiO}_{2} \\
\mathrm{Fe}_{3} \mathrm{O}_{4} \\
\mathrm{AllOH})_{3}\end{array}$ \\
\hline \multicolumn{4}{|c|}{ Semiquantitative Spectrographic Analysis (\%) } \\
\hline $\mathrm{Ag}$ & $<$ & 0.005 & $<0.005$ \\
\hline Al & & 1.5 & $>2 n$ \\
\hline Al1 & 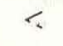 & 0.02 & $<0.02$ \\
\hline B & & 0.02 & $\cap \cap 1$ \\
\hline $\mathrm{Ba}$ & $<$ & 0.002 & $<0.002$ \\
\hline $\mathrm{Be}$ & $<$ & 0.001 & $<0.001$ \\
\hline $\mathrm{Bi}$ & $<$ & 0.01 & 0.01 \\
\hline $\mathrm{Ca}$ & & 0.2 & 0.01 \\
\hline $\mathrm{Cd}$ & $<$ & 0.04 & $<0.04$ \\
\hline Co & & 0.06 & $<0.005$ \\
\hline $\mathrm{Cr}$ & & 0.5 & 0.1 \\
\hline Cs & $<$ & 0.6 & $<0.6$ \\
\hline $\mathrm{Cu}$ & & 0.15 & 0.3 \\
\hline $\mathrm{Fe}$ & & 20 & 0.1 \\
\hline $\mathrm{Hf}$ & $<$ & 0.04 & $<0.02$ \\
\hline K & & 0.04 & $<0.04$ \\
\hline $\mathrm{Li}$ & $<$ & 0.02 & $<0.02$ \\
\hline $\mathrm{Mg}$ & & 0.01 & 1.2 \\
\hline $\mathrm{Mn}$ & & 0.3 & 0.15 \\
\hline Mo & & 0.7 & 0.04 \\
\hline $\mathrm{Na}$ & & 0.07 & 0.04 \\
\hline $\mathrm{Nb}$ & $<$ & 0.02 & $<0.02$ \\
\hline $\mathrm{Ni}$ & & 1.2 & 0.02 \\
\hline $\mathbf{P}$ & $<$ & 1 & $<1$ \\
\hline $\mathrm{Pb}$ & $<$ & 0.01 & $<0.01$ \\
\hline $\mathrm{Rb}$ & $<$ & 0.15 & $<0.15$ \\
\hline Sh & $<$ & 0.04 & $<0.04$ \\
\hline $\mathrm{Si}$ & & 0.4 & 1 \\
\hline Sn & $<$ & 0.005 & $<0.005$ \\
\hline Ta & & 1.5 & $<0.15$ \\
\hline Th & $<$ & 0.04 & $<0.04$ \\
\hline $\mathrm{Ti}$ & & 0.04 & 0.01 \\
\hline$U$ & $<$ & 0.3 & $<0.3$ \\
\hline v & & 0.04 & $<0.005$ \\
\hline$w$ & $<$ & 0.08 & $<0.08$ \\
\hline$Z n$ & $<$ & 0.08 & 1.2 \\
\hline $\mathrm{Zr}$ & & 0.01 & $<0.002$ \\
\hline
\end{tabular}

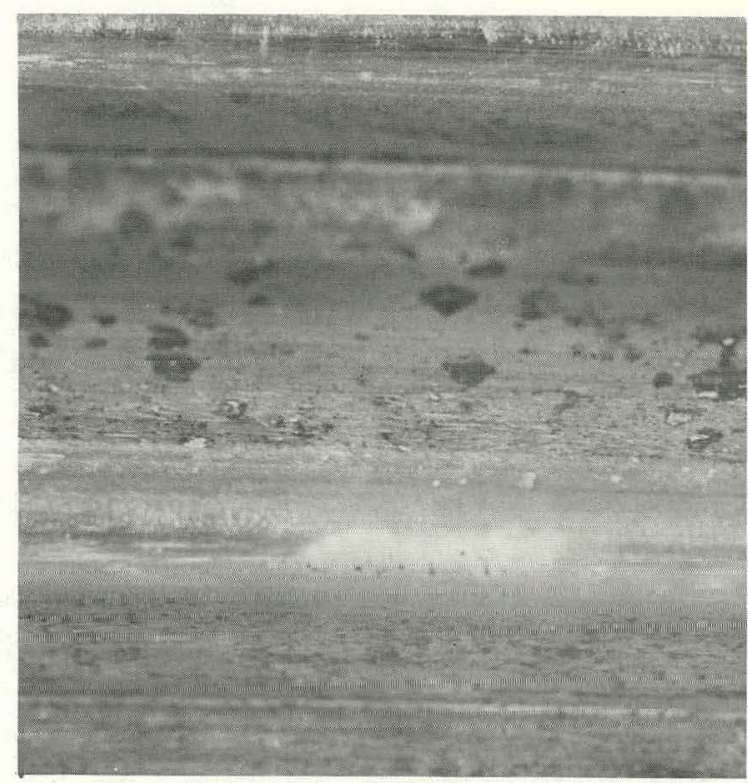

Figure 4. CORROSION PITTING IN THE THREAD ROOTS OF PRESSURE VESSEL 2.

The results are summarized in Figure 5. The maximum measured flaw was $0.307 \mathrm{~mm}$ deep and $1.143 \mathrm{~mm}$ wide. This flaw was located in the first quarter turn of the first thread. Flaw sizes diminished toward the bottom of the vessel.

\section{Liner Geometry and Condition}

The aluminum cooling liner used in PV-2 is composed of two cylindrical shells. The inner shell has had water channels cut in its outside surface. These shells were then shrink fitted together (Figure 6). Both the top and bottom mushrooms seal against the liner. The purpose of this liner is to keep the temperature of the vessel walls below $95^{\circ} \mathrm{C}\left(200^{\circ} \mathrm{F}\right)$.

The location and appearance of the liner corrosion is revealed in Figure 7. Chemical analysis (Table 1) on samples indicated no unusual corrosion products. Cooling of the vessel occurs during the depressurization cycle. When parts are removed from the autoclave, humid air is drawn into the vessel and the water vapor apparently condenses in the form of droplets in the region 

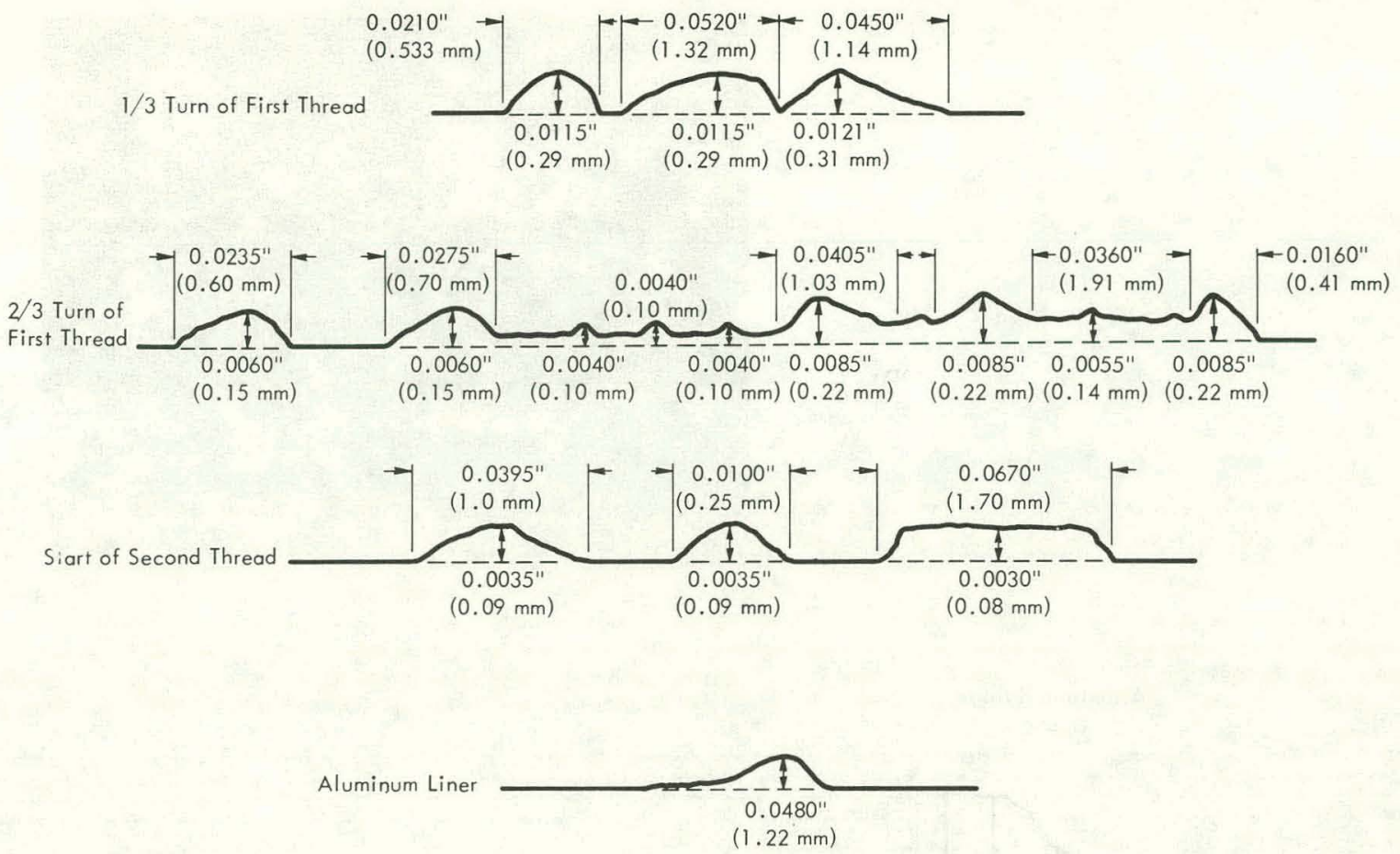

Figure 5. CORROSION-PIT DIMENSIONS FOR THE THREAD ROOT AND ALUMINUM LINER OF PRESSURE VESSEL 2.

between the lower mushroom and bottom seal. The areas of deepest corrosion contained pits that were approximately $1.52 \mathrm{~mm}$ deep and $7.62 \mathrm{~mm}$ long, as seen in Figure 5.

\section{Fracture Analysis of the Lower Thread Region}

A detailed stress analysis of the region of the threads in the bottom of both PV -1 and PV-2 has been made by Pohto. (2) The stress field at the base of the first thread is composed of both a tensile and bending component, as illustrated in Figure 8. A general elastic-stress-analysis solution for a cracked body of the geometry indicated in Figure 8 does not exist, but solutions for the configuration shown in Figure 9 are available.

Two models were used to predict the critical crack size for $\mathrm{PV}-2$ and to

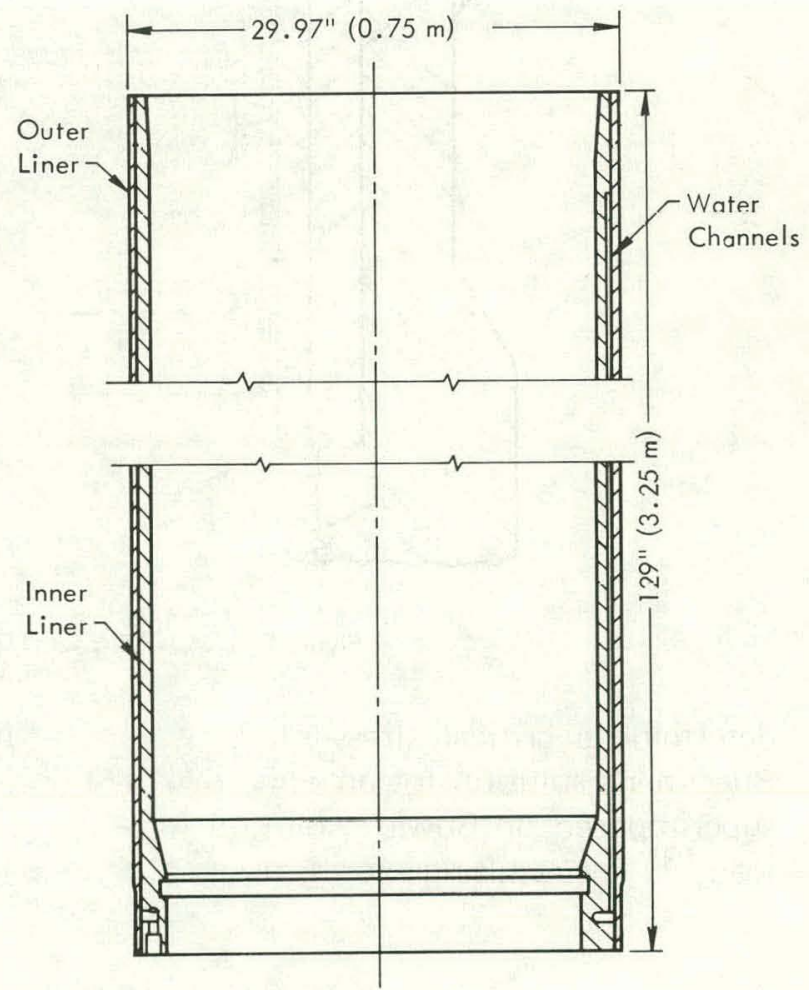

Figure 6. ALUMINUM COOLING LINER FOR PRESSURE VESSEL 2. 


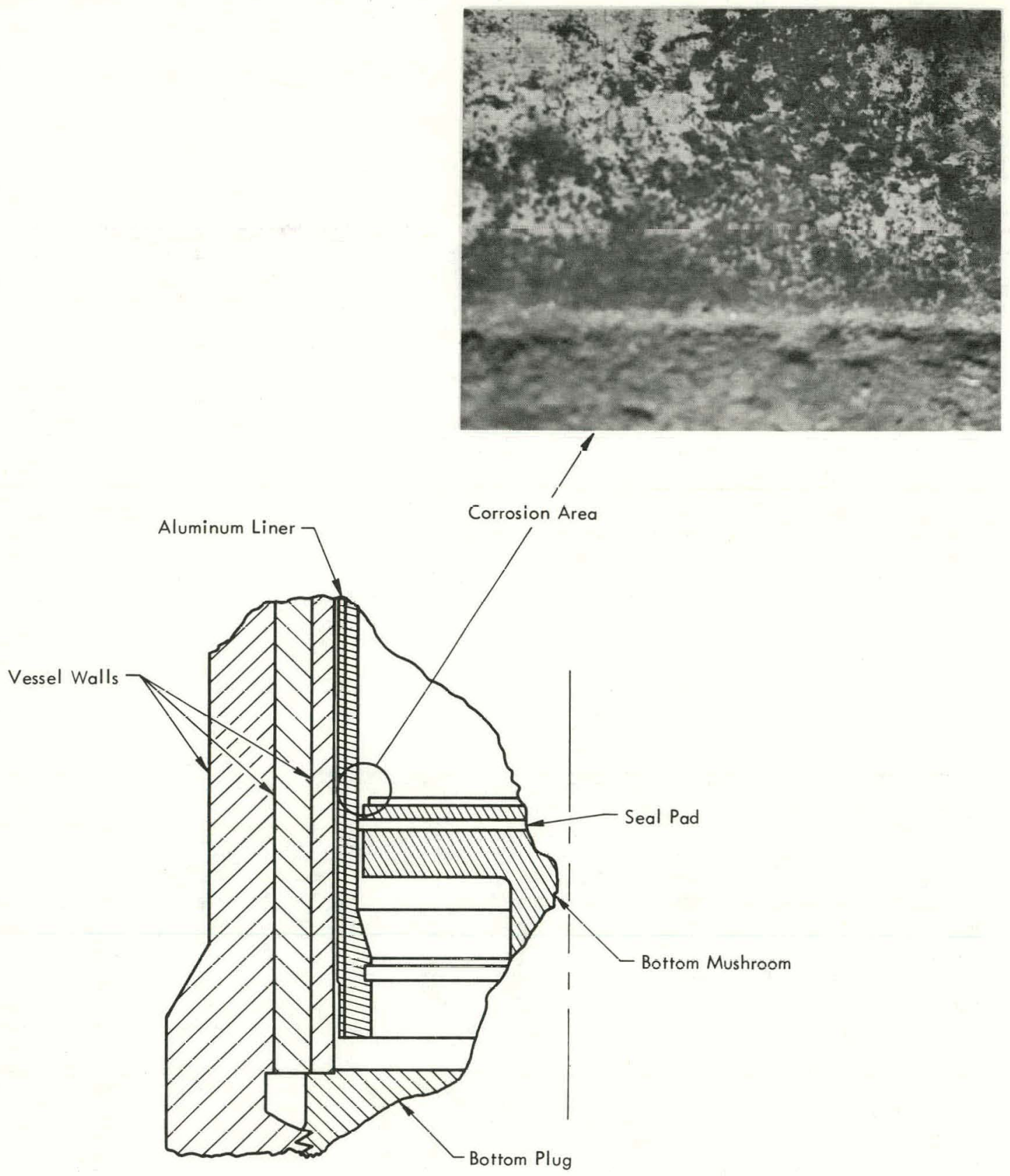

Figure 7. LOCATION OF THE LINER CORROSION.

determine a critical stress-intensity factor for PV-1. The first model was composed of Bueckner's solution for an edge crack in a finite-width plate subjected to a bending moment superimposed on Bowie's solution for an edge crack in a finite-width plate under a tensile load. (3) The resulting expression for the stress-intensity factor is:

$$
K_{1}=\frac{6 M}{(t-a)^{3 / 2}} g(a / t)+\sigma_{O}(a \pi)^{1 / 2} K(a / t),
$$



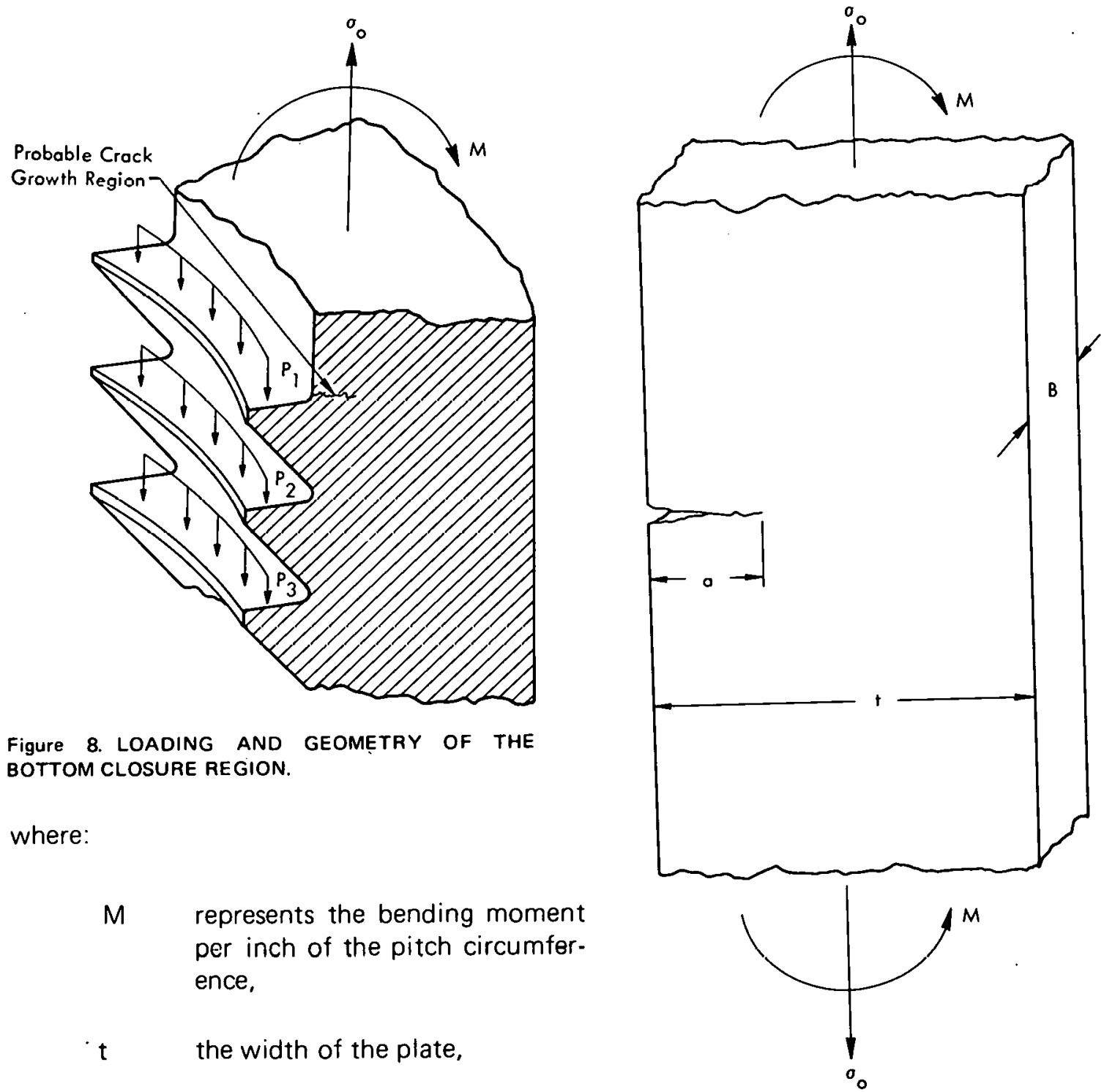

Figure 8. LOADING AND GEOMETRY OF THE BOTTOM CLOSURE REGION.

where:

M represents the bending moment per inch of the pitch circumference,

$t$ the width of the plate,

a the crack depth, and

Figure 9. MODEL GEOMETRY FOR THE PRES SURE VESSEL ANALYSIS.

$\sigma_{0} \quad$ the remote tensile stress.

The values of $g(a / t)$ and $k(a / t)$ are presented in tabular form. Using least-squares curve-fitting procedures, the following expressions were found for $g(a / t)$. and $k(a / t)$ :

$$
g(a / t)=\frac{a / t}{1.2603 a / t+0.07642}, \text { and }
$$

$$
k(a / t)=\frac{1}{0.9510-1.1971 \mathrm{a} / \mathrm{t}} .
$$


Using a crack depth equal to the thread depth $(25.25 \mathrm{~mm})$ plus the initial crack depth $(3.28 \mathrm{~mm})$, as determined from the photographs of the failure surfaces of PV-1, a critical stress-intensity factor of 86.29 $\mathrm{MPa} \cdot \sqrt{\mathrm{m}}$ was found.

A special low-alloy steel (Table 2) was used in the construction of both PV-1 and PV-2. The critical stress-intensity factor for this alloy was not known by the manufacturer. Critical crack lengths for PV-2 can be determined from the $K_{I}$. value found for PV-1. A graph of the critical crack length as a function of the operating pressure for PV-2, as predicted by the model of Bueckner and Bowie, is presented in Figure 10.

The second model involved solutions for the same geometry using boundary-collocation techniques. The solution was made by Gross and Srawley $(4,5)$ and takes the form: (b)

$$
\begin{aligned}
K_{1}= & \frac{M}{B t^{3 / 2}}\left[138 \mathrm{a} / \mathrm{t}-221(\mathrm{a} / \mathrm{t})^{2}+783(\mathrm{a} / \mathrm{t})^{3}\right]^{1 / 2} \\
& +\sigma_{\mathrm{O}}(\mathrm{t})^{1 / 2}\left[\frac{\mathrm{a} / \mathrm{t}}{0.27033-0.49274 \mathrm{a} / \mathrm{t}}\right]^{1 / 2},
\end{aligned}
$$

where $M$ represents the total bending moment and $B$ the thickness of the plate.

In the present solution, $B$ is equal to the pitch circumference. A critical stress-intensity factor of $86.12 \mathrm{MPa}-\sqrt{\mathrm{m}}$ was found for PV-1. A plot of critical crack length as a function of the operating pressure for PV-2, as predicted by the model of Gross and Srawley, is given in Figure 11.

\section{Fatigue Life Analysis}

Several theories have been proposed to predict component life, using fracture-mechanics and fatigue-crack-growth information. A very good survey of various models is presented by Hoeppner and Krupp. (6) The models take the general form of:

(b) The shape factor for the tensile component represents a least-squares curve fit on the tabulated results of Gross and Srawley by the author. 


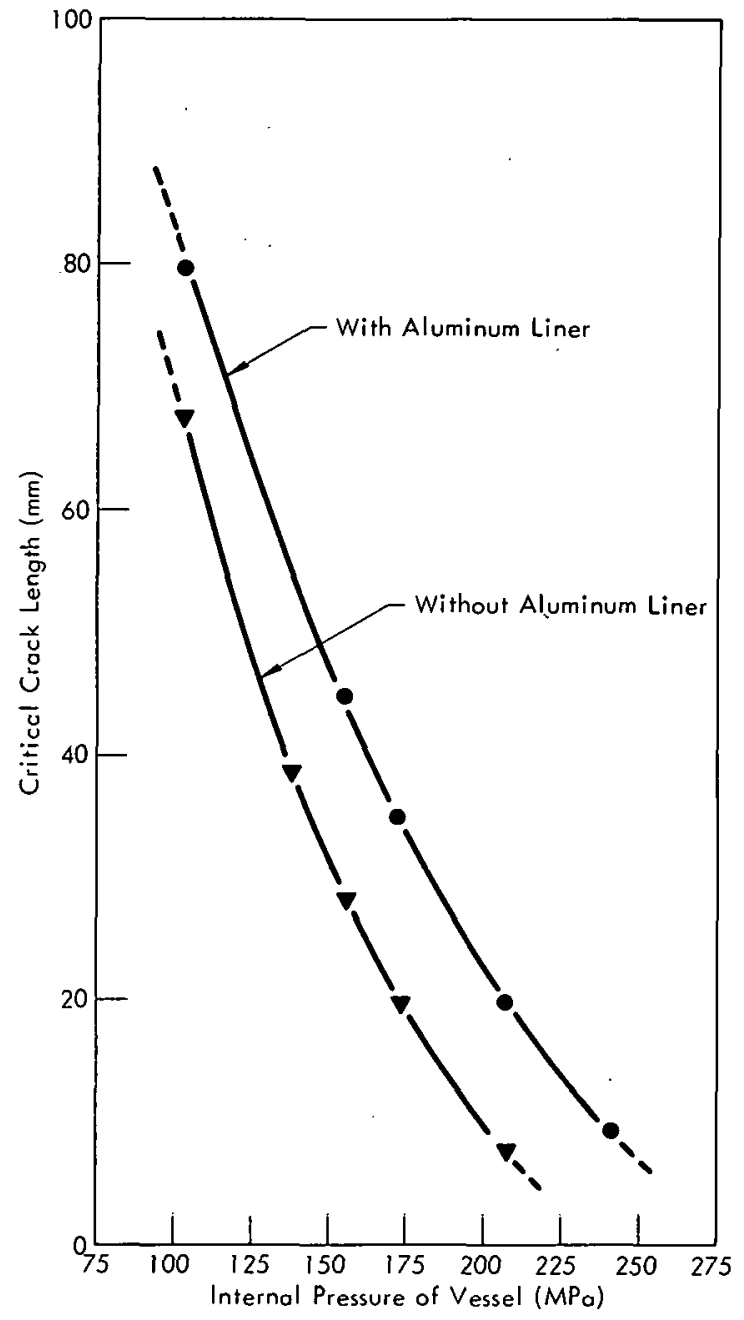

Figure 10. CRITICAL .CRACK LENGTHS FOR VAR. IOUS OPERATING PRESSURES OF PRESSURE VES. SEL 2. (Model: Bueckner and Bowie)

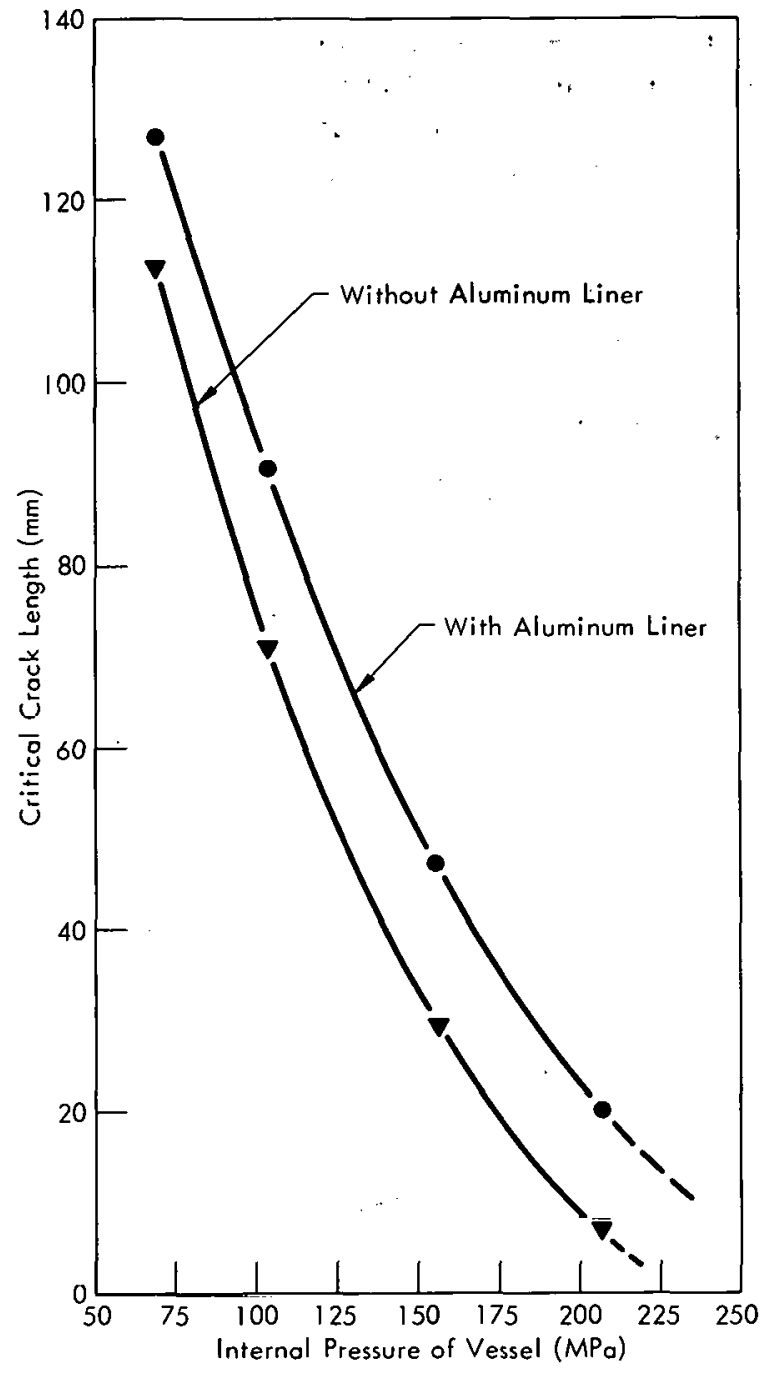

Figure 11. CRITICAL CRACK LENGTHS FOR VARIOUS OPERATING PRESSURES OF PRESSURE VESSEL 2. (Model: Gross and Srawley)

$$
\frac{\mathrm{da}}{\mathrm{dn}}=C(\Delta K)^{n}
$$

where $\mathrm{da} / \mathrm{dn}$ represents the crack-growth rate per cycle, $\mathrm{C}$ and $\mathrm{n}$ are material parameters, and $\Delta K$ is the range variation in the stress-intensity factor for a load cycle.

No data were found for the steels used in PV -1 and PV-2 which would allow the value of $C$ and $n$ to be determined. Brothers and Yukawa (7) present data (Figure 12) for a Ni-Cr-Mo-Va low-alloy steel. If the steel used in the pressure vessels is similar, then estimates of the material parameters can be made, resulting in the following equation:

$$
\frac{d a}{d n}=3.73 \times 10^{-10}\left(\Delta K_{.}\right)^{2.85}
$$


Barsom, et al, (8) in a study of high-yieldstrength steels, presents a lower-limit curve for making conservative estimates of fatigue life. His equation is:

$$
\frac{d a}{d n}=0.66 \times 10^{-8}(\Delta K)^{2.25}
$$

Using both equations, predictions were made on the fatigue life of PV-1 when operating at $207 \mathrm{MPa}$. Equation 6 predicts a life of 1515 cycles, while Barsom's lower-bound equation predicts a life of 1152 cycles. Both numbers indicate that major macrocrack growth was occurring in the PV-1 vessel during at least two thirds of the life of the vessel.

Life predictions for PV-2 were also made, using the Gross and Srawley equation to determine the stress-intensity factors. Analyses were made (Figures 13 and 14) with and without the aluminum liner. From these analyses, the life of the vessel, at $207 \mathrm{MPa}$ and without the aluminum liner, is only from 2600 to 3500 cycles.

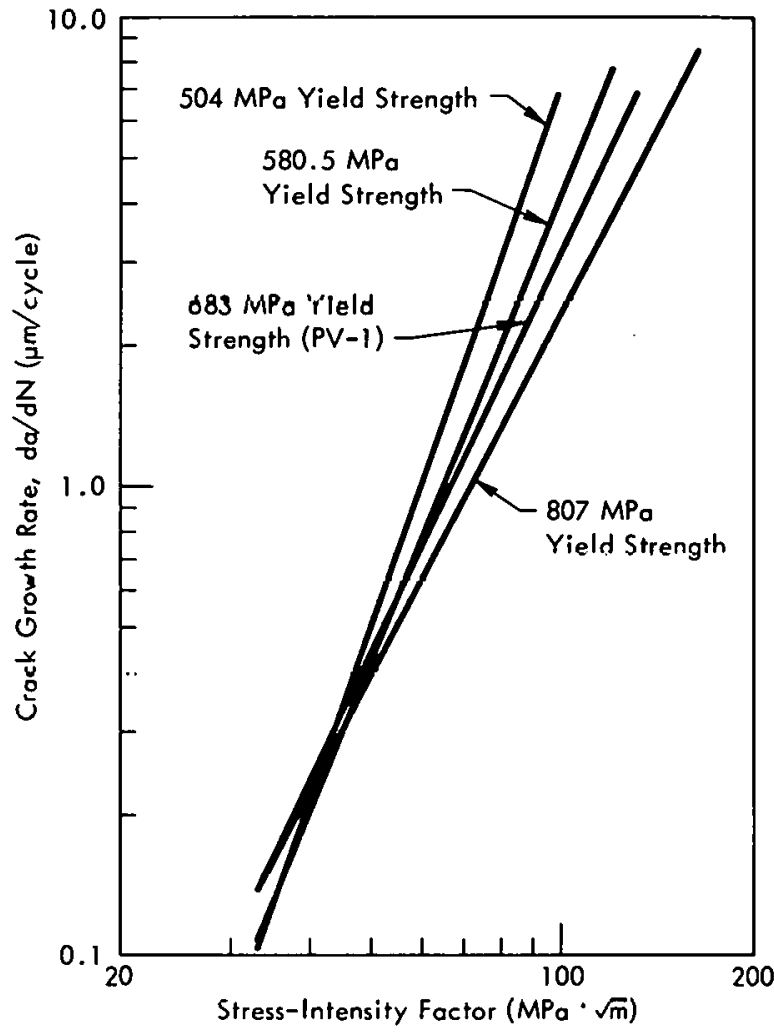

Figure 12. CRACK GROWTH RATE AS A FUNCTION OF THE STRESS-INTENSITY FACTOR FOR LOW-ALLOY STEEL AT VARIOUS YIELD STRENGTHS. (From Brothers and Yukawal

The liner aided in reducing the end loads and extending the life of the vessel. Thus, with the liner and at a maximum pressure of $207 \mathrm{MPa}$, a life of 9200 to 13,000 cycles would be expected. However, pressures in this range are no longer possible due to the limitation imposed by the maximum allowed stresses for the liner. Consequently, the life of the lower thread region at the allowable maximum pressure of $103.4 \mathrm{MPa}$ should be greater than 97,000 cycles.

\section{Aluminum Liner Analysis}

An analysis of the liner stresses was made in 1964 for an internal pressure of $137.9 \mathrm{MPa}$. (1) The results of a similar analysis for an internal pressure of $103.4 \mathrm{MPa}$ are presented in Figure 15. The hoop-stress profile for both the inner and outer shell of the liner is included.

The water channels cut into the outer surface of the inner liner serve as a stress riser. The stress-concentration factor for this geometry can be found $(y)$ and gives a maximum hoop stress of $132 \mathrm{MPa}$. The hoop-stress distribution in the inner liner shell in the region of the channel should be similar to that shown in Figure 16.

Critical-Flaw-Size Determination - Assuming that fatigue crack growth can occur at the bottom of the corrosion areas in the liner, a model of an elliptic surface crack can be used to determine the critical flaw size, as seen in Figure 17. The elliptical crack will not be growing 


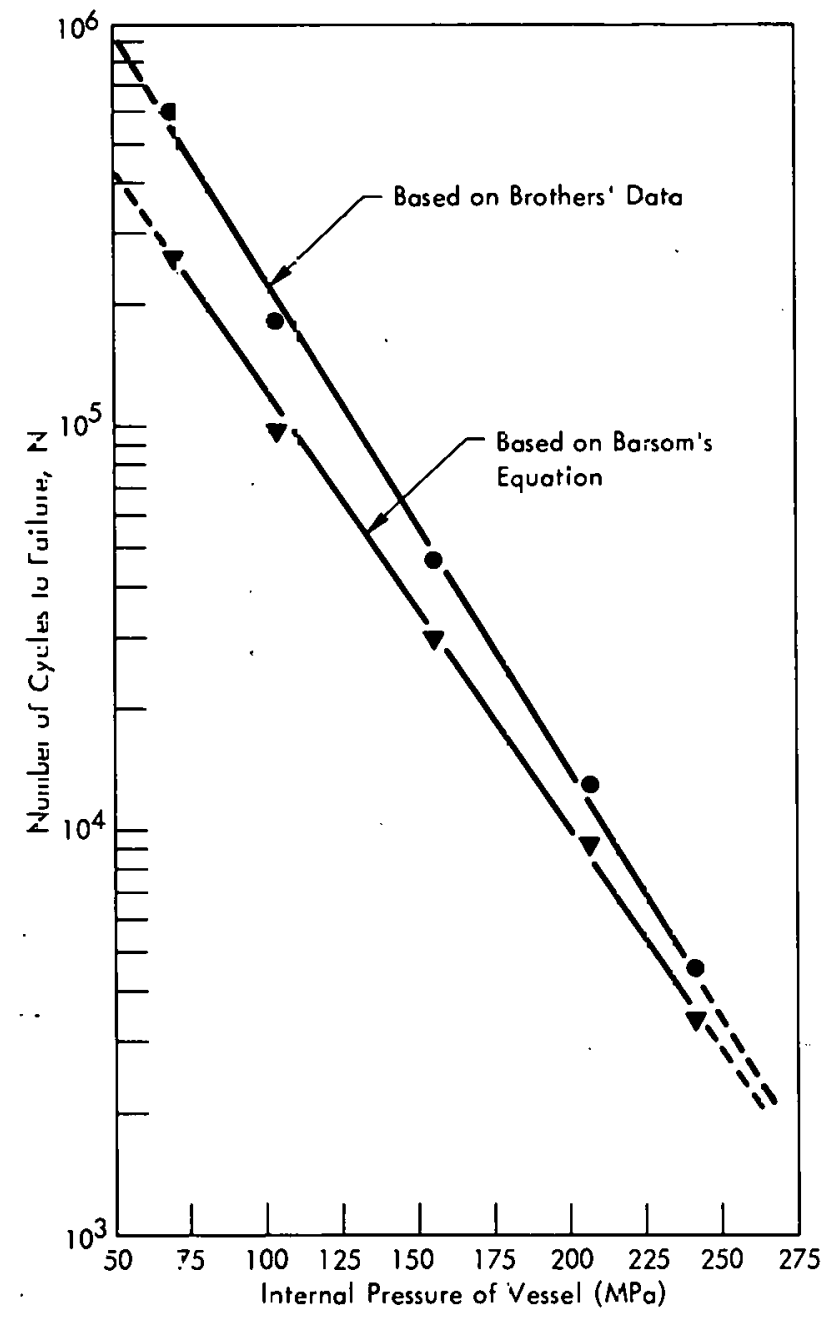

Figure 13. =ATIGUE LIFE OF PRESSURE VESSEL 2 WITH THE ALUMINUM LINJER.

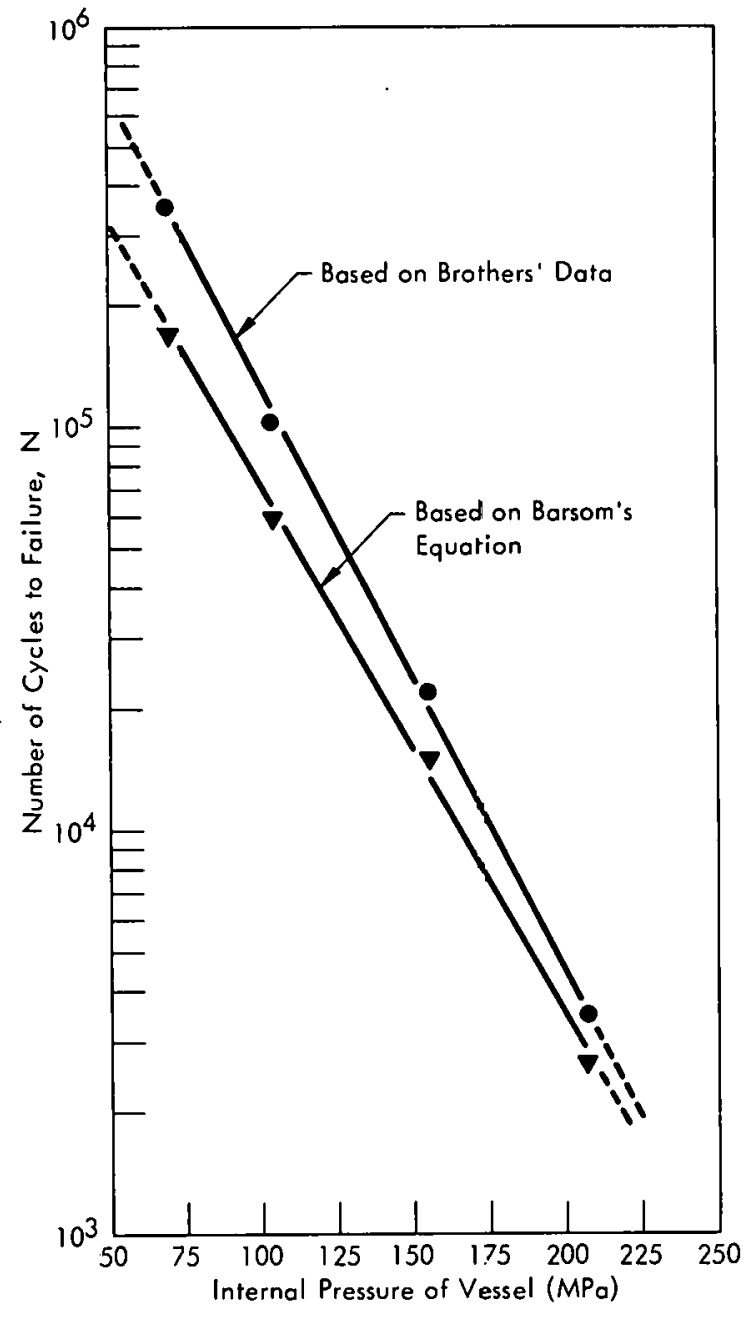

Figure 14. FATIGUE LIFE OF PRESSURE VESSEL 2 WITHOUT THE ALUMINUM LINER. 


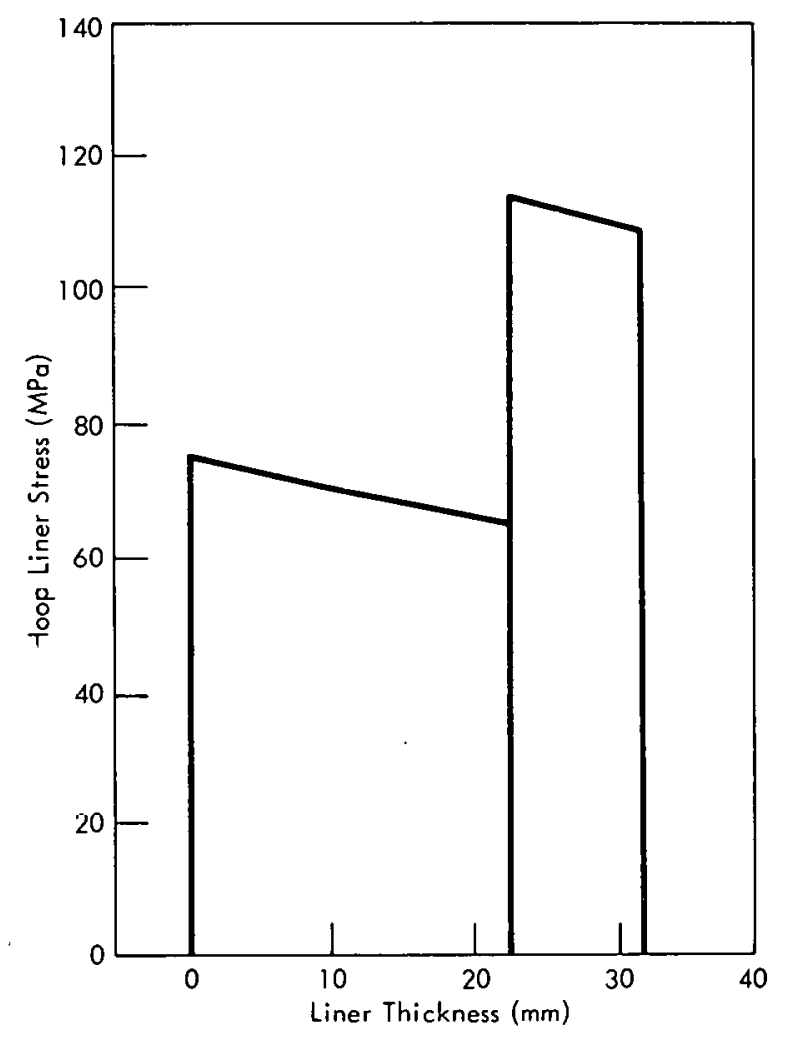

Figure 15. PROFILE OF HOOP STRESSES IN THE ALUMINUM LINER AT AN INTERNAL PRESSURE OF $103.4 \mathrm{MPa}$.

in an area of uniform stress due to the presence of the water channel; but, in order to simplify the problem, a uniform stress field equal to the maximum stress (132 $\mathrm{MPa}$ ) will be used. This procedure should lead to conservative results. As the crack grows, the ratio of the major to minor axis $(a / b)$ will be assumed to remain constant. The solution for critical flaw size used in this analysis was obtained by Kobayashi and Moss. (10) Their solution is presented in graphical form. A curve fit was applied to their data, resulting in the following equation:

$$
\begin{gathered}
K_{I}=\sigma_{0} \frac{\sqrt{\pi a}}{\phi}\left[1.078-0.00374 \mathrm{a} / \mathrm{t}-0.0682(\mathrm{a} / \mathrm{t})^{2}\right. \\
\left.+0.6545(\mathrm{a} / \mathrm{t})^{3}-0.8755(\mathrm{a} / \mathrm{t})^{4}+0.911(\mathrm{a} / \mathrm{t})^{5}\right]
\end{gathered}
$$

where:

$\sigma_{0}$ represents the tensile stress field, 
a the minor axis of the ellipse (crack depth),

t the wall thickness, and

$\phi \quad$ the elliptic integral of the second kind.

The $K_{I C}$ (critical stress-intensity factor) for Type 7039-T61 aluminum is 31.9 MPa- $\sqrt{m} .(11) \mid$ Equation 8 gives a critical crack depth of 0.523 inch.

Fatigue-Life Determination - Experimental data on crack growth rates for Type 7039-T61 aluminum could not be found, but Browerman and White felt da/dN curves for Type 7075-T6 aluminum could be used with good results in the upper $\Delta k$ range. The following equations $(12,13)$ were used to predict the fatigue life of the liner:

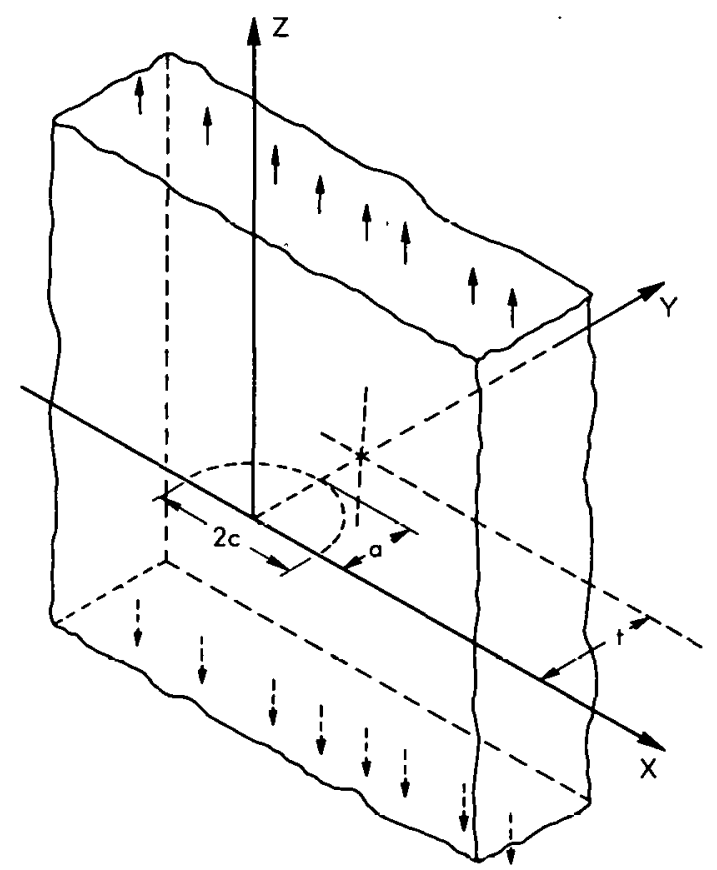

Figure 17. SEMIELLIPTICAL SURFACE FLAW IN A PLATE SUBJECTED TO UNIAXIAL TENSION.

$$
\begin{aligned}
& \frac{d a}{d N}=2.52 \times 10^{-8}(\Delta k)^{2.69}, \text { and } \\
& \frac{d a}{d N}=7.653 \times 10^{-9}(\Delta k)^{3.202}
\end{aligned}
$$

The total number of cycles $(N)$ to failure, as found from Equation 9, is 13,722 cycles. Equation 10 predicts a life of 12,532 cycles.

A much more rapid failure may occur if a long crack develops at the base of one of the water channels. A life of only 1500 to 2000 cycles is expected if this failure occurs. This failure may not happen from fatigue cracking, since the endurance limit for Type 7039-T61 aluminum should be greater than 151.7 MPa. (The stress at the base of the channel is only $131 \mathrm{MPa}$.) If extensive corrosion has occurred in these channels, increasing the localized hoop stress above the endurance limit, then early fatigue may occur.

\section{DISCUSSION OF RESULTS}

Charpy impact tests were conducted on samples cut from PV-1. The transition temperature for the $50 \%$ ductile fracture was in the range of 63 to $75^{\circ} \mathrm{C}$. Drop-weight tests were also conducted. The nil-ductility temperature (NDT) of the steel was established at $54^{\circ} \mathrm{C}$. Sailors and Corten (14) proposed an empirical relationship between the critical stress-intensity factor and results from the Charpy impact test for temperatures below the NDT point, thus: 


$$
\frac{K^{2}}{\mathrm{IC}}=8(\mathrm{CV})
$$

where $K_{I C}$ is in $k s i-\sqrt{i n}, E$ is in psi, and $C V$ is in $\mathrm{ft}$ lbs. The range of Charpy impact data for PV-1 is from 16.0 to $35.4 \mathrm{~J}$, with an average of $25.73 \mathrm{~J}$. The corresponding range for the critical stress-intensity factor is from 58.5 to $86.9 \mathrm{MPa}-\sqrt{\mathrm{m}}$, with an average value of 73.6 $\mathrm{MPa}-\sqrt{\mathrm{m}}$. Values calculated from the fracture models indicated a $\mathrm{K}_{\mathrm{IC}}$ of $86.1 \mathrm{iMPa}-\sqrt{\mathrm{m}}$, which lies within the range indicated by the Charpy impact data, although using an edge-cracked plate to determine stress-intensity factors for a hollow cylinder with an internal circumferential crack leads to high values. Also, a circular geometry tends to restrain movements found in the edge-notched plate. Swedlow and Ritter $(15)$ discuss this problem for a material with a modulus of elasticity of $68.9 \mathrm{GPa}$ and a Poisson's ratio of 0.400 . For this material in a geometry similar to $P V-1$, the $K_{I C}$ value would be overestimated by more than $5 \%$. Actual $K_{I C}$ values for PV-1 and PV-2 may lie in the 70 to $76 \mathrm{MPa}-\sqrt{\mathrm{m}}$ range. Exact solutions would require a finite-element analysis.

A comparison of the fatigue analysis on PV-2 with various studies made using stress-number of cycle (S-N) diagrams is provided in Table 3. Results of the present analysis are in similar ranges as the earlier studies. At least three factors will affect these life estimates:

Table 3

1. The initial proof test at $310.3 \mathrm{MPa}$ left the material at the base of the first thread root in compression. This type of loading tends to extend the fatigue life.

2. The da/dN curves are generated from high-frequency $(>1000$ cycles/min) fatigue testing, while the vessel is actually subjected to very-low-frequency cycling (50 cycles/year). Low-frequency cycling can shorten the fatigue life by a factor of 2 to 3 or more. The vessel has been through 2400 cycles of which 1551 cycles were at a pressure of $155.1 \mathrm{MPa}$. These cycles have reduced the expected life of the vessel.

COMPARISON OF THE FATIGUE LIFE CALCULATION

\begin{tabular}{|c|c|c|c|c|c|}
\hline \multirow{2}{*}{$\frac{\text { Vessel }}{\text { PV-1 }}$} & \multirow{2}{*}{$\begin{array}{c}\begin{array}{c}\text { Pressure } \\
\text { (MPa) }\end{array} \\
206.8\end{array}$} & \multirow{2}{*}{$\begin{array}{c}\begin{array}{c}\text { Number of } \\
\text { Cycles } \\
\text { to Failure }\end{array} \\
1,554\end{array}$} & \multicolumn{3}{|c|}{$\begin{array}{c}\text { Life Prediction } \\
\text { from } \\
\text { Present Analysis } \\
\text { (cycles) }\end{array}$} \\
\hline & & & 1,152 & & 1,515 \\
\hline PV-2 & 206.8 & & 2,600 & & 3,500 \\
\hline PV-2 & 155.1 & $\begin{array}{r}13,000^{(1)} \\
5,000^{(2)}\end{array}$ & 15,000 & & 22,100 \\
\hline PV-2 & 137.9 & $32,000^{(1)}$ & 23,800 & & 36,000 \\
\hline PV-2(3) & 137.9 & $115,000^{(1)}$ & 43,700 & & 72,000 \\
\hline PV-2(3) & 155.1 & $60,000(1)$ & 30,000 & & 47,000 \\
\hline PV.2(3) & 103.4 & & 97,000 & & 184,000 \\
\hline
\end{tabular}

(1) From Compendium of Gas Autoclave Engineering Studies (1)

(2) From Aspects of the Brittle Fracture Failure of a 30-Inch, 30,000-psi Isostat with Thrcoded Closure. (2)

(3) PV-2 with aluminum liner.

3. A final area of much concern involves the possibility of hydrogen embrittlement. This concern was expressed by Landon (16) of the LLL in a recent visit to $Y-12$. Corrosion will introduce hydrogen into the steel. The stress concentrations at the thread root are large enough to cause crack growth due to hydrogen embrittlement. If this occurs, then the life of the vessel could be greatly shortened.

All of these factor influence the final fatigue life to a degree that is difficult to determine. For this reason, the life numbers should be used only as a guide. Periodic examinations of the vessel at various intervals are essential for safe operation of the vessel. 


\section{Conclusions and Recommendations}

In view of the present study, the following conclusions and recommendations are presented:

1. The corrosion pits in the root of the first four threads should be removed.

2. Preventive corrosion coatings should be applied to both the threads and the aluminum liner.

3. Any sharp discontinuity in the liner caused by corrosion should be removed.

4. An elliptical surface flaw 0.523 inch deep with an $a / b$ ratio of 0.2 is required before catastrophic failure of the liner occurs.

5. A total of 12,000 cycles will be required before cracks can grow from the present surface corrosion sites to a critical length in the liner.

6. Extensive corrosion in the water channels may greatly shorten the life of the inner shell of the liner.

7. The present limiting pressure of $103.4 \mathrm{MPa}$ appears to be a safe and reasonable limit. It is recommended that this limit be retained. At this maximum pressure, the fatigue life of the thread region is expected to be greater than 97,000 cycles.

8. The top of the vessel should be covered when not in use, and the chamber should be purged with dry nitrogen.

9. The possibility of a similar purge in the region of the bottom threads should be considered.

10. Changes in the operational procedures to miminize the cooling effects of the depressurization cycle on the bottom of the vessel should be considered.

11. Effects of operating the vessel above the NDT to prevent brittle fracture should be analyzed.

12. Monitoring possible crack growth in the region of the bottom threads, using acoustic-emission techniques, should be considered.

13. The areas in which corrosion has occurred should be checked at the end of 150 cycles, or 3 years, to determine if the corrosion-preventive coatings are performing their function. The length of time to the next inspection can than be determined. 


\section{REFERENCES}

(1) Compendium of Gas Autoclave Engineering Studies, Edited by C. E. Muzzall, Y-1478; Union Carbide Corporation-Nuclear Division, Oak Ridge Y-12 Plant, Oak Ridge, Tennessee; November 2, 1964.

(2) Pohto, H. A.; Aspects of the Brittle Fracture Failure of a 30-Inch, 30,000-psi /sostat with Threaded Closure, Y-1758; Union Carbide Corporation-Nuclear Division, Oak Ridge Y-12 Plant, Oak Ridge, Tennessee; April 30, 1971.

(3) Paris, P. C. and Sih, G. C.; "Stress Analysis of Cracks", Fracture Toughness and Its Applications, ASTM STP 381. pp 41 - 44; Baltimore, Maryland (1965).

(4) Gross, B., Srawley, J. E., and Brown, W. F., Jr; Stress-Intensity Factors for a Single-Edge-Notch-Tension Specimen by Boundary Collocation of a Stress Function, NASA TN-D-2395; August 1964.

(5) Gross, B. and Srawley, J. E.; Stress-Intensity Factors for Single-Edge-Notch Specimens in Bending or Combined Bending and Tension by Boundary Collocation of a Stress Function, NASA TN D-2603; January 1965.

(6) Hoeppner, D. W. and Krupp, W. E.; "Prediction of Component Life by Application of Fatigue and Growth Knowledge", Engineering Fracture Mechanics, 6, pp 47-70 (1974).

(7) Brothers, A. J. and Yukawa, S.; "Fatigue Crack Propagation in Low-Alloy Heat-Treated Steels", Journal of Basic Engineering, pp $19-27$; Transactions of the ASME, March 1967.

(8) Barsom, J. M., Imhof, E. J., and Ralfe, S. T.; "Fatigue-Crack Propagation in High-Yield-Strength Steels", Engineering Fracture Mechanics, 2, pp $301-317$ (1971).

(9) Neuber, H.; Theory of Notch Stresses; Published by Springer-Vulag, Berlin, 1958; Translated by the United States Atomic Energy Commission, AEC-tr-4547, June 1961.

(10) Kobayashi, A. S., and Moss, W. L.; "Stress-Intensity Magnification Factors for a Surface-Flawed Tension Plate and Notched Round Bar". Proceedings of 2nd International Conference on Fractures; Brighton, England (1969).

(11) Plane-Strain Fracture Toughness $(K / C)$ Data Handbook for Metals, AD-773673; Compiled by W. F. Matthews, Army Materials and Mechanics Research Center; December 1973.

(12) Dunegan, H. L. and Harris, D. D.; "Acoustic Emission Techniques", Experimental Techniques in Fracture Mechanics pp 38 - 75; Edited by A. S. Kobayaski (1973).

(13) Hudson, M. C.; A Study of Fatigue and Fracture in 7075-T6 Aluminum Alloy in Vacuum and Air Environments, NASA TND-7262; October 1973. 
(14) Sailors, R. H. and Corten, H. T.; "Relationship Between Material Fracture Toughness using Fracture Mechanics and Transition Temperature Tests", Fracture Toughness, Part II, Proceedings of the 1971 National Symposium on Fracture Mechanics, ASTM STP 514, pp 164 - 191; American Society for Testing and Materials (1972).

(15) Swedlow, J. L. and Ritter, M. A.; "Toward Assessing the Effects of Crack Front Curvature (CFC)", Stress Analysis and Growth of Cracks, Part 1, Proceedings of the 1971 National Symposium on Fracture Mechanics, ASTM STM 513, pp 79 - 89; American Society for Testing and Materials (1972).

(16) Landon, P. R.; Lawrence Livermore Laboratory, Livermore, California; Personal Communication; From Meeting Held at the Oak Ridge Y-12 Plant, June 1974. 


\section{Distribution}

\section{Brigham Young University}

High-Pressure Data Center

Energy Research and Development Administration - Oak Ridge

Hickman, H. D.

Leed, R. E.

Zachry, D. S., Jr

Harwood Engineering - Walpole, MA

Hëwhall, D. W.

\section{Lawrence Livermore Laboratory}

Burton, W.

Broadman, G.

Lakner, J. F.

Landon, $P$.

Stromberg, H. D.

Los Alamos Scientific Laboratory

Baker, $F$.

Donham, B. J.

Oak Ridge Gaseous Diffusion Plant

Patton, F. S.

Stief, S. S.

Wilcox, W. J., Jr

Oak Ridge National Laboratory

Merkle, J.

Pickel, T. W./Dyslin, D. A.

\section{Oak Ridge Y-12 Plant}

Alvey. H. E.

Bernander, N. K.

Burditt, R. B.

Burkhart, L. E.

Ellingson, R. D.

Foulk, D. L.

Fraser, R. J.

Greene, R. F.

Gritzner, V. B.

Hensley, C. E.

Huddleston, R. L. 
Johnson, C. E./Bently, E. L.

Union Carbide Corporation - S. Charleston

Jones, F. W.

Kahl, K. G.

Keith, A.

Kite, H. T.

Klein, C. F.

McNeill, R. L.

Knight, C.E.

Kois, J. P.

Lundin, M. I.

Mills, J. M., Jr

Oliphant, G.W.

Perry, A. E.

Phillips, L. R.

Pohto, H. A.

Schreyer, J. M.

Smith, H. F., Jr

Smith, R. D.

Stoner, H. H.

St. Onge, C. D.

Sturm, R. G. (Huntsville, Alabama)

Thompson, W. F.

Tilson, F. V.

Valentine, C. K.

Weathersby, W. E.

Whitson W. K.

Yaggi, W. J./Googin, J. M.

$Y-12$ Central Files (5)

$Y-12$ Central Files (master copy)

$Y-12$ Central Files (route copy)

$Y-12$ Central Files ( $Y$-12RC)

Zerby, C. D.

Paducah Gaseous Diffusion Plant

Leviri, R. W.

Penn State University

Babrowsky, A. R.

Sandia - Albuquerque

Hopper, R. E.

University of Missouri - Rolla

Davis, R. F. 